\title{
Porcine Circovirus
}

\author{
G. Saikumar and Tareni Das
}

\begin{abstract}
Porcine circovirus (PCV) infections associated with post-weaning multisystemic wasting syndrome (PMWS) are characterized by weight loss, respiratory distress, jaundice, etc. Although PCV2 infection is ubiquitous, the prevalence of clinical disease is lower and the most common form is PCV2 subclinical infection. Recently, a novel porcine circovirus (PCV3) has been identified in pigs in the USA that is associated with porcine dermatitis nephropathy syndrome, acute myocarditis and multisystemic inflammation, etc. Genetic heterogeneity of PCV2 has been studied in Indian pig population. Different genotypes like PCV2a-2D, PCV2b-1C, PCV2d and recombinant strain between PCV2a-2C and PCV2b-1C are reported from different studies. PCV2 has been discovered in human faeces, human vaccines and beef. But its pathogenicity in humans is not clear. PCV detection is based on common golden standard techniques including nucleic acid and antigen detection in the tissues, in situ hybridization (ISH) and immunohistochemistry (IHC) using monoclonal or polyclonal antibody against PCV2, respectively. The commercial vaccines available are effective in reducing the severity of clinical diseases and improving production parameters. Recently, antiviral compounds have also shown promising results against PCV2. This chapter summarizes aetiology, epidemiology, transmission, immunopathobiology, diagnosis, prevention and control of porcine circovirus.
\end{abstract}

\section{Keywords}

Porcine circovirus - PCV · Porcine kidney cell line - Post-weaning multisystemic wasting syndrome · Aetiology · Epidemiology · Transmission · Immunopathobiology $\cdot$ Diagnosis $\cdot$ Prevention and control

\footnotetext{
G. Saikumar $(\varangle) \cdot$ T. Das

Division of Pathology, ICAR-Indian Veterinary Research Institute (ICAR-IVRI),

Izatnagar, Uttar Pradesh, India
} 


\subsection{Prologue}

Porcine circovirus (PCV) is a small non-enveloped icosahedral virus containing a circular single-stranded DNA genome. It was first recognized in 1974 as a contaminant in porcine kidney cell line (PK-15) without any cytopathic effect (Tischer et al. 1974). Under experimental condition, this virus did not produce any aliment in pigs (Tischer et al. 1986). Later on in 1991, a novel PCV associated with a sporadic disease called as post-weaning multisystemic wasting syndrome (PMWS), characterized by weight loss, respiratory distress, jaundice, etc., was reported from Saskatchewan, Canada (Harding 1996; Clark 1997). The variant which was associated with PMWS was designated as PCV2 and the non-pathogenic one as PCV1 (Meehan et al. 1998). Retrospective study revealed that PCV2 has been circulating in pig population more than a decade (Jacobsen et al. 2009). As clinical disease was reproduced experimentally when PCV2 was inoculated along with other infectious or non-infectious agent, it was considered as necessary but not sufficient factor to develop clinical disease (Allan et al. 1999; Ellis 2003).

The PCV2 was found associated with a number of clinical diseases which were collectively termed as porcine circovirus disease (PCVD) and porcine circovirus associated diseases (PCVAD) in Europe and North America, respectively (Segalés et al. 2005; Opriessnig et al. 2007). PCVAD was recognized as a globally emerging disease, having huge impact on swine industry causing severe economic loss. Although PCV2 infection is ubiquitous, the prevalence of clinical disease is lower and the most common form is PCV2 subclinical infection (PCV2-SI) (Segalés 2012). The economic impact of PMWS and PCV2-SI for the pig industry, England for the year 2008, prior to introduction of vaccination was estimated to be $£ 52.8$ million and $£ 88$ million per year, respectively, during epidemic period (Alarcon et al. 2013). In 2016, a novel porcine circovirus (PCV3) was identified in pigs in the USA associated with porcine dermatitis nephropathy syndrome, acute myocarditis and multisystemic inflammation, etc. (Phan et al. 2016; Palinski et al. 2017). PCV3 is not strongly genetically related to other PCV and it has been observed that PCV3 has emerged over the last 50 years (Saraiva et al. 2018). The current paper summarizes aetiology, epidemiology, transmission, immunopathobiology, diagnosis, prevention and control of porcine circovirus.

\subsection{Virus}

PCV1, PCV2 and PCV3 belong to genus Circovirus under family Circoviridae. They are small, non-enveloped, icosahedral viruses containing single-stranded negative-sense circular DNA genome organized in a typical ambisense pattern. The genome sizes for PCV1, PCV2 and PCV3 are 1759 nucleotides, 1767-1768 nucleotides and 2000 nucleotides, respectively. PCV1 and PCV2 contain eleven predicted open reading frames (ORF), out of which ORF1, ORF5, ORF7 and ORF10 are encoded by positive strand and transcribed clockwise and others (ORF2, ORF3, ORF4, ORF6, ORF8, ORF9 and ORF11) are encoded by negative strand or 
complementary strand and transcribed anticlockwise (Hamel et al. 1998; He et al. 2013). ORF1 and ORF2 are major open reading frames which are oriented in opposite direction. ORF1 encodes for replication protein and ORF2 for capsid protein which is having immunodominant antigenic epitopes. ORF1 of PCV1 and PCV2 share $83 \%$ nucleotide identity and $86 \%$ amino acid identity whereas ORF2 of PCV1 and PCV2 share $67 \%$ nucleotide and $65 \%$ amino acid sequence identity. The rep protein of PCV3 shared 55\% identity to rep protein of bat and $48 \%$ identity to rep protein of PCV2, and the cap protein of PCV3 shared $35 \%$ amino acid identity to bat circoviruses and 24-26\% amino acid identity to PCV1 and PCV2, respectively (Phan et al. 2016). ORF3 is one of the major proteins of PCV and also most variable protein with $60 \%$ amino acid identity between PCV1 and PCV2. ORF3 region is embedded within ORF1 region and oriented in opposite direction. The ORF3 protein of PCV2 is involved in apoptosis. The fourth one ORF4 has been suggested to be located in ORF3 region and transcribed in the same direction. The PCV1 and PCV2 have $83 \%$ predicted amino acid identity for ORF4. It plays an important role in suppressing caspase activity and regulating CD4+ and CD8+ lymphocyte population (Hamel et al. 1998; He et al. 2013). The multiplication of PCV is speculated to involve rolling circle method (Allan and Ellis 2000; Mankertz et al. 2004; Phan et al. 2016). The viruses mainly rely on host-encoded protein because of their limited encoding capacity. PCV2 requires actively multiplying cells for replication (Tischer et al. 1987; Mankertz et al. 2004).

PCV2 has been divided into PCV2 group 1 and PCV2 group 2 with genome sizes 1767 nucleotides and 1768 nucleotides, respectively (Olvera et al. 2007). North American laboratories considered grouping into North American isolate, PCV2a, which comes under PCV2 group 2 and European-like isolates, PCV2b, which is under PCV2 group 1 (Gagnon et al. 2007). PCV2 strains were divided into three different genotypes (PCV2a, PCV2b and PCV2c) based on proportion of different nucleotide sites in ORF2 (Segalés et al. 2008). PCV2a was subdivided in four clusters (2A to 2D) and PCV2b into three clusters (1A to 1C) (Olvera et al. 2007). PCV2a was predominant genotype in pig population worldwide since 2000. PCV2b has been present in Europe and Asia since 1997 and PCV2c was identified in archived serum samples from Denmark (Dupont et al. 2008). Later on, in 2009, two new genotypes PCV2d and PCV2e were detected (Wang et al. 2009; Zhai et al. 2011; Xiao et al. 2015). Emergence of new recombinant genotype PCV1/2a, having ORF1 of PCV1 and ORF2 of PCV2, has been reported in Canada with very low prevalence rate in 2008 (Gagnon et al. 2010). In Northeast India, emergence of PCV2a and PCV2b has been reported (Bhattacharjee et al. 2015). A novel genotype PCV2f was reported in three out of 23 PCV2 strains identified from the archived pig tissue samples collected between 1996 and 1999 in China (Bao et al. 2018). After introduction of PCV2 vaccination in the USA in 2006, PCV2d-2 is found to be predominant genotype in the USA which is a second genotypic shift after a major genotypic shift in mid-2000 replacing PCV2a with PCV2b (Xiao et al. 2016). Recently, PCV3 has also been reported from different parts of the world such as the USA (Phan et al. 2016), China (Shen et al. 2017), Korea (Kwon et al. 2017), Europe (Stadejek et al. 2017), etc. 


\subsection{Epidemiology}

First, PCV1 was encountered in un-inoculated PK-15 cell line ATCC-CCL 33. Later on, PCV1 was recovered from pig foetal materials, wasting syndrome in France, wild boar, human rotavirus vaccine, etc. PCV1 infection is spread worldwide. Serum antibodies to PCV1 have been demonstrated in pigs in Germany, Canada, New Zealand, Great Britain and Northern Ireland. Much of the seropositivity might be due to cross-reactivity to PCV2 antigen in indirect immunofluorescence or indirect immunoperoxidase assays (Allan et al. 2012). But actually in field cases prevalence of PCV1 is very low (Ellis et al. 2000). Also serum antibodies to PCV1 have been detected in other species like humans (30.2\%), mice (12-69\%) and cattle (35\%) in Germany by IIF and ELISA which need further confirmation (Tischer et al. 1995).

PCV2 is having a widespread geographical distribution and is one of the emerging swine pathogens. After its first discovery in Canadian weaning piglet in 1991, it has been subsequently reported from Spain, France, Hungary, UK, Brazil, Uruguay, Oceania, Australia, Caribbean, Cuba, Israel, South Africa, Uganda, Korea, China, etc. (Afolabi et al. 2017). The virus is ubiquitous in swine population reaching seroprevalence up to $100 \%$. PCV2 has also been reported from different parts of India from different clinical cases of swine. In an organized swine farm, located in the state of Uttar Pradesh (North India) with a history of mummification, stillbirth, neonatal mortality and decreased litter size, 12 out of 70 litters examined were found positive for PCV2 (Sharma and Saikumar 2010).

Genetic heterogeneity of PCV2 has been studied in Indian pig population. Different genotypes like PCV2a-2D, PCV2b-1C, PCV2d and recombinant strain between PCV2a-2C and PCV2b-1C were reported (Anoopraj et al. 2015). There is also report of infection of PCV2 in a piggery unit from Southern India, Tamil Nadu having high incidence of stillbirth and neonatal mortality (Kumar et al. 2014; Karuppannan et al. 2016). PCV2 has been reported in Assam. Out of 54 stillbirth and mummified foetuses collected from pig farms in Kamrup districts of Assam during 2013-2014, 16.6\% samples were PCV2 positive and 7.4\% both porcine parvovirus (PPV) and PCV2 positive (Pegu et al. 2017). There is also report of high seroprevalence of PCV2 (80.8\% in 2014, 79.1\% in 2015, 96.2\% in 2016) by antibody ELISA in 11 districts of Meghalaya, India, out of 1899 serum samples collected from different age groups of pigs (Mukherjee et al. 2018b). In another study, out of 249 serum samples collected between 2014 and 2016 from Meghalaya, India, PCV2 antibodies were detected in $83.93 \%$ suspected serum by ELISA and in $62.25 \%$ by PCR. Also $18.94 \%$ (36/190) tissue samples were positive for PCV2. Molecular characterization indicated prevalence of PCV2a, PCV2b-1c, PCV2d and recombination genotype of PCV2a and PCV2b in India (Mukherjee et al. 2018a).

In Canada and in Costa Rica, antibodies to PCV2 were detected in $82.4 \%$ out of 386 serum samples and $14.2 \%$ out of 322 serum samples collected from normal healthy pigs (Liu et al. 2002). In Poland, PCV2 was detected in $75.6 \%$ cases out of 312 tested wild boar tonsil samples by real-time PCR (Fabisiak et al. 2012). Between 
2013 and 2015, prevalence of PCV2 is reported to be significantly higher in Eastern China (87.3\%) than Western China (47.6\%) (Yuzhang et al. 2016). In Thailand, during 2009-2015, PCV2 was detected in 306 (44.09\%) samples collected from 56 farms (80\%) with PCV2d as the predominant genotype (Nattrat et al. 2017).

PCV2 infection is characterized by high prevalence and low morbidity. PCV2 is an essential factor required for the development of PCV-associated diseases. As $\mathrm{PCV} 2$ is detected in healthy pigs, the presence of other triggering factors is essential for the outcome of PCV2 infection. They are mainly classified into four groups, i.e. viral factors, host factors, housing and management factors, co-infections and immunomodulation.

\subsubsection{Viral Factors}

Virus is ubiquitous in nature and it is present in most of the pig farms across the world. All the infected pigs do not develop disease. Some are severely diseased while others are healthy. The disease occurs in different clinical manifestations. But no significant difference is observed in virus genome involved in different clinical conditions and also between affected and unaffected farms (Grierson et al. 2004). Also no PCV2 molecular markers for virulence have been identified between affected and unaffected farms (De Boisseson et al. 2004). Virulence can also be altered with minor change in genome as PCV2 was attenuated after 120 time's serial passage in cell culture resulting in two amino acid mutations in capsid protein (Fenaux et al. 2004). Genotypic shift is associated with more severe diseases. It was observed after PCV2b replaced PCV2a in mid-2000. After PCV2 vaccination, PCV2d is found to be predominant genotype in the USA during 2014-2016 because of its greater ability to multiply under vaccination pressure (Xiao et al. 2016).

\subsubsection{Host Factor}

All breeds of pigs are susceptible to infection. But in field condition, it has been observed that certain genetic lines of pigs are more or less susceptible to disease as compared to others. Experimentally, it was found that Landrace breeds were more susceptible to PCVAD than Duroc and Large White pigs (Opriessnig et al. 2006a). Under field condition, lower mortality was observed in pure Pietrain or Large White and Pietrain cross as compared to Large White and Duroc cross pigs (Lopez-Soria et al. 2011). High titre of maternal antibody is protective as compared to low titre maternal antibody. Host variation in onset of adaptive immune response also affects the susceptibility and outcome of disease. Age-related susceptibility to PCV2 was also observed which is directly related to maternal antibody level. In the USA, under field condition and experimental conditions, 12-16-week pigs are more affected with PCVAD in comparison to 2-7-week-old pigs (Shen et al. 2012). 


\subsubsection{Housing Management Factors}

It has been observed that various factors like on farm management, housing, vaccination schedule, husbandry condition, biosecurity and hygiene practices are strongly related to PCVAD (Grau-Roma et al. 2011; Rose et al. 2012). Housing like large pen in weaning facility; common pit between different fattening rooms and proximity to other pig farms; hygiene and husbandry practices like sows in poor condition, early weaning, pig mixing, purchase of replacement gilts, short empty period in nursery and farrowing sector; use of farm boar for semen collection; vaccination schedule like vaccination of gilts against PRRS; use of separate vaccine like Erysipelothrix rhusiopathiae and PPV in gilts; etc., are found to be risk factors for development of PCVAD whereas vaccination against atrophic rhinitis is protective. Biosecurity measures like shower facility were also found effective. Some of the practices modify the course of PCV favouring early infection while others trigger virus replication directly or indirectly (Andraud et al. 2009).

\subsubsection{Co-infections}

A number of pathogens like virus, bacteria and mycoplasma infection along with PCV2 are able to increase incidence of PCV2 or exacerbate the disease. Most potential triggering pathogens are PRRSV, PPV and Mycoplasma hyopneumoniae (Allan et al. 2000; Opriessnig et al. 2004; Ha et al. 2008). Some other pathogens are also found as a result of immunosuppression or by chance as co-circulating pathogens. Other important pathogens which are associated with PCV2 are swine influenza, hepatitis E virus, pseudorabies virus, classical swine fever virus, porcine enterovirus, corona virus, Actinobacillus pleuropneumoniae, Pasteurella multocida, Haemophilus parasuis, E. coli, Cryptosporidium parvum, Chlamydia species, Aspergillus species, Candida albicans, etc. (Kim et al. 2003a; Grau-Roma et al. 2011). The speculation is that co-infections may enhance replication of PCV2 and their accumulation in immune cells or interfere with clearance of virus by changing cytokine profile (Opriessnig and Halbur 2012; Segalés et al. 2013).

\subsubsection{Immunomodulation}

Immune stimulation may enhance PCV2 infection and disease outcome. It was observed that gnotobiotic piglets immunized with keyhole limpet hemocyanin emulsified in incomplete Freund's adjuvant or commercial bacterin containing mineral oil adjuvant developed PMWS following vaccination (Krakowka et al. 2007). Also severe microscopic lesions and virus load were observed in PCV2-infected colostrum-deprived piglets vaccinated with commercially available modified live PRRS vaccine as compared to non-vaccinated piglets (Allan et al. 2007). Potentiation of PCV2 replication after immunostimulation may be due to massive activation of certain cells like macrophages in lymphoid system. The effect of immune 
suppression on PCVAD has also been studied. Injection of cyclosporine and dexamethasone before PCV2 infection resulted in increased PCV2 replication and granulomatous lymphadenitis as compared to control (Krakowka et al. 2002; Kawashima et al. 2003).

Recently, a novel porcine circovirus categorized as PCV3 has been identified. In 2015, this novel circovirus, PCV3, was detected in the USA from three pigs showing cardiac lesions and multi-organ inflammation through metagenomic analysis (Phan et al. 2016). Again PCV3 was reported from a case of PDNS and reproductive failure in the USA through metagenomic sequencing (Palinski et al. 2017). In 2016, PCV3 was detected for the first time in China from pyretic and pneumonic piglets (Shen et al. 2017). In China, PCV3 was identified in 24 out of 35 farms and suspected to be an important factor in reproductive failure (Ku et al. 2017). PCV3 was detected in 132 out of 222 cases without any clinical infection signs from Shandong province, China (Zheng et al. 2017). In Korea, 44.2\% (159/360) and 72.6\% (53/73) PCV3 prevalence is reported at individual and farm level, respectively, using pen side oral fluid sample (Kwon et al. 2017). In Europe, PCV3 was detected in 12 out of 14 Polish farms and in PCV3-positive farms, PCV3 was detected in 5.9\% to $65 \%$ serum pools by real-time PCR out of total 1050 serum samples collected between 2014 and 2017 (Stadejek et al. 2017). PCV3 has also been described in Italy (Faccini et al. 2017), Sweden (Ye et al. 2018), Northern Ireland and England (Collins et al. 2017).

\subsection{Transmission}

Porcine circoviruses are transmitted in different modes. PCV2 can be secreted in various secretions and excretions of the body like nasal, tonsilar, bronchial and ocular secretions, faeces, urine, semen, saliva and milk of both clinically affected and infected but apparently healthy animals. Clinically affected animals shed more virus than infected but clinically healthy animals.

Direct contact with infected animals is the more efficient route of virus transmission. The oronasal route is the most likely route of transmission. Also naive pigs fed orally with uncooked tissues of viraemic pigs resulted in infection. Indirect transmission also occurs when pigs were kept in adjacent pens. Porcine circoviruses are shed in milk of infected sow and can be transmitted to offspring by oral route through milk. PCV1 and PCV2 were detected in the colostrums collected from 33 sows in Japan by virus isolation and PCR (Shibata et al. 2006). In an experimental study, sows infected with PCV2 intranasally at 93 days of gestation shed virus from the first day of lactation to 27th day of lactation. But it is not clear whether virus is secreted as free or cell-associated form as virus multiplies in macrophages of mammary gland, but most viruses are detected in cell-free portion or whey portion of milk (Ha et al. 2009).

There is also possibility of airborne transmission which cannot be ruled out. High concentration of PCV2 DNA up to $10^{7}$ genome copies per cubic millimetre of air was detected by quantitative PCR in the Canadian swine confinement building but its infectivity was not studied (Verreault et al. 2010). 
House flies also act as vectors for transmission of PCV2. The flies have on farm potential to carry and transmit PCV because of their close association with pigs and the environment. It was studied in a pig farm where identical PCV2b DNA was isolated both from faeces of weaner and nursery pigs and house flies. These insects form a measure of environmental contamination at a pig farm site by PCV2 (Blunt et al. 2011). Also mosquitoes like Culex species can serve as mechanical vectors for transmission of PCV2 (Yang et al. 2012).

Cross-species transmission of circoviruses has also been reported. USA beef contained circoviruses which showed $99 \%$ similarity to PCV2b (Li et al. 2011). In China, cross-species transmission between the pig and buffalo was also reported recently (Zhai et al. 2017). In China, 6.15\% prevalence of PCV2 in goats was reported with PCV2d genotypes (Wang et al. 2018). PCV2 was also reported in rat samples in swine farms. In China, 31.6\% (30/95) rat samples were found positive for PCV2 by PCR (Zhai et al. 2016). PCV2 has been discovered in human faeces, human vaccines and beef. But its pathogenicity in human is not clear. There are various possible routes of PCV infection in humans such as ingestion or contact with pork products, ingestion of undressed beef or raw milk, drinking raw water, vaccine contamination, airborne transmission, vector transmission, xenotransplant infection, etc. (Zhai et al. 2012).

Vertical transmission has also been reported both in natural condition and experimental condition. Transplacental transmission results in reproductive abnormalities. Following intranasal infection of pregnant sows 3 weeks prior to farrowing resulted in PCV2-infected, aborted and live-born piglets (Park et al. 2005). Experimentally in utero inoculation of swine foetuses with PCV2 at late stage of gestation resulted in stillborn, mummified and weak-born piglets at farrowing. Also antibodies to PCV2 were found in the sera and thoracic fluids of both abnormal and normal presuckle piglets (Johnson et al. 2002). PCV2 can replicate in embryos before 21 days of pregnancy and might result in embryonic death in most of the cases (Mateusen et al. 2007).

PCV2 has been demonstrated in the semen samples. In an experiment, mature boars were infected intranasally with PCV2. The presence of PCV2 antibodies was detected in the serum from 11 dpi to 90 dpi by IFA and PCV2 DNA was detected in serum from 4 dpi to 35 dpi by PCR and nested PCR and in semen from 5 dpi to 47 dpi (Larochelle et al. 2000). In Korea, 13, 26 and 11 were positive for PCV2 by conventional PCR, by nested PCR and by virus isolation, respectively, out of total 98 semen samples collected from 1-year-old boars in 49 herds and also greater amount of DNA was detected in the seminal fluid and non-sperm fraction (Kim et al. 2003b). Persistently infected boars may continue to shed virus in the semen up to 71 weeks and it did not affect percentage of morphologically normal and live sperms (McIntosh et al. 2006). PCV2 antigen was also demonstrated in the cytoplasm of a macrophage and fibroblasts of seminal vesicles with PCV2 DNA in the semen of an 11-month-old boar having history of illness and infertility by nested PCR (Opriessnig et al. 2006b). PCV2 can be transmitted via artificial insemination with semen spiked with PCV2. It was observed in an experiment where PCV2-free mature female pigs were artificially inseminated with PCV2 DNA-negative semen 
spiked with PCV2a and PCV2b. Viraemia was observed in both groups in comparison to control group, those artificially inseminated with PCV2 DNA-negative semen. Sows inseminated with PCV2a-spiked semen failed to become pregnant and sows inseminated with PCV2b semen gave birth to viraemic live-born piglets, PCV2-infected stillbirth and mummified foetuses (Madson et al. 2008).

\subsection{Immunopathogenesis}

Porcine circoviruses can multiply in different types of cells like epithelial cells, mononuclear cells, endothelial cells, fibrocytes, etc. PCV attaches with host cells through interaction with host cell glycosaminoglycans like heparin sulphate and chondroitin sulphate B, and it enters epithelial cells by actin and Rho-GTPase and monocytic cells by clathrin-mediated endocytosis (Misinzo et al. 2005, 2006, 2009). Acidic medium, i.e. endosome-lysosomal acidification, is required for PCV2 multiplication (Misinzo et al. 2008). After entry into cells, PCV2 DNA enters into the nucleus with the help of many cellular factors and multiplies there by rolling circle model. PCV DNA replication is initiated during $\mathrm{S}$ phase of growth as many required cellular enzymes are expressed during this phase (Tischer et al. 1987). HSP 70 and HSP 27 positively regulate DNA replication whereas cyclin A and HMG co-A reductase negatively regulate replication (Liu et al. 2013, 2014; Tang et al. 2013; Huang et al. 2014). The ubiquitin proteasomal system (UPS) is required for effective PCV2 replication, viral protein expression and RNA transcription in a cell cycle-dependent manner (Cheng et al. 2014). The ORF3 causes degradation of regulator of G protein signalling 16 (RGS 16) through ubiquitin proteasomal system (UPS) and enhances translocation of nuclear factor kappa B into the nucleus through extracellular signalling pathways (ERP 1/2) resulting in increased virus proliferation and increased IL-6 and IL-8 mRNA transcript leading to more inflammatory response around host cells during the early stage of PCV2 infection (Choi et al. 2015). Progeny viruses begin to appear after $30 \mathrm{~h}$ postinfection.

PCV infection enhances cellular oxidative stress which further influences its replication in PK 15 cells. Malondialdehyde concentration is increased and glutathione and superoxide dismutase concentration is found to be decreased in $48 \mathrm{~h}$ after PCV infection (Chen et al. 2013). Factors like ochratoxin which increase oxidative stress may enhance PCV multiplication (Gan et al. 2015).

PCV2 infection results in host immunosuppression, characterized by lymphoid depletion. Lymphoid depletion affected B cells, T cells and NK cells. Virus replication is enhanced in actively dividing lymphocytes than resting lymphocytes ( $\mathrm{Yu}$ et al. 2007, 2009). The virus multiplies in lymphoblastoid cells and causes its lysis (Rodríguez-Cariño et al. 2011). Lymphoid depletion is also induced by apoptosis which could be either due to activation of caspase 3 and caspase 8 by ORF3 protein or by increased $\mathrm{p} 53$ or by activation of $\mathrm{NF}-\kappa \beta$ or by Fas-Fas ligand activation (Liu et al. 2006, 2007; Chang et al. 2007). Apoptosis signal-regulating kinase-1 (ASK-1) also plays a vital role in regulating PCV2-induced apoptosis (Wei et al. 2013). Decreased proliferative activity in lymphoid cell could also be a major cause of 
lymphoid depletion (Mandrioli et al. 2004). PCV2 can induce anti-apoptotic response during the early stage of viral infection through activation of phosphatidylinositol 3-kinase/Akt pathways resulting in suppression of premature apoptosis for improved virus growth after infection (Wei et al. 2012).

PCV2 is most commonly associated with monocytic cells and dendritic cells (DC). Virus can persist in DC for days without any signs of apoptosis or modulation of cell surface marker. Virus uses DC for its transmission and spread (Vincent et al. 2003). The presence of PCV2 in macrophages suppresses its microbicidal activity by inhibiting production of $\mathrm{O}_{2}^{-}$and $\mathrm{H}_{2} \mathrm{O}_{2}$. Also alveolar macrophage infected with PCV2 produces high amount of TNF- $\alpha$, IL-8, granulocyte colony-stimulating factor (CSF), neutrophil chemotactic factor, monocyte chemotactic protein-I, etc. (Chang et al. 2006). CpG oligodeoxyribonucleotide present in PCV2 genome inhibits production of IFN- $\alpha$ and TNF- $\alpha$ by plasmacytoid DC; as a result co-stimulatory potential to myeloid DC and responses induced after ligand stimulation of TLR7 and TLR9 are negatively impaired (Vincent et al. 2007). PCV2 dsDNA also prevents actin polymerization and endocytosis in DC, thus strongly suppressing basic innate immune response and increasing secondary infection (Balmelli et al. 2011).

Increased expression of IL-10 is also reported in peripheral blood mononuclear cells and lymphoid tissues of animals infected with PCV2 (Doster et al. 2010). Higher IL-10 expression is observed in bystander cells as compared to infected cells as a result of paracrine effect. IL-10-mediated immune suppression may result in pathology associated with PCV2 infection. PCV2 also strongly induces IL-1 $\beta$ and IL-8 expression in both naive and PCV2-infected pigs suggestive towards chronic inflammation. But PMWS-affected pigs produce less IL-2, IL-4 and IFN- $\gamma$ as compared to healthy ones which may be due to lymphoid depletion (Darwich et al. 2003a, b; Darwich and Mateu 2012).

\subsection{Clinical Features of PCVAD}

\subsubsection{PCV2 Systemic Disease (PCV2-SD)}

It is clinically characterized by weight loss, respiratory distress, diarrhoea, pale skin, jaundice, enlarged subcutaneous lymph nodes, etc. (Harding and Clark 1997). Morbidity is $4-30 \%$ commonly, occasionally $50-60 \%$, and mortality is $4-20 \%$ (Segalés and Domingo 2002).

\subsubsection{PCV2 Lung Disease (PCV-LD)}

It is characterized by respiratory distress and dyspnoea. It also plays an important role in porcine respiratory disease complex (PRDC) along with other pathogens like Mycoplasma hyopneumoniae, swine influenza, PRRS virus, etc., in 8- to 26-weekold pigs which is characterized by decreased feed efficiency and growth rate, anorexia, fever, cough and dyspnoea (Anoopraj et al. 2014; Kim et al. 2003a). 


\subsubsection{PCV2 Enteric Disease (PCV2-ED)}

It is characterized by enteritis. Most of the PCV2 enteric disease cases in fields are from 8- to 16-week age group pigs (Kim et al. 2004).

\subsubsection{PCV2 Reproductive Disease (PCV2-RD)}

The clinical manifestations of PCV2-RD include abortions, stillbirths, mummification and pre-weaning mortality (West et al. 1999). PCV2-RD is rare in field condition which may be due to its high seroprevalence in adult pigs and absence of clinical disease in breeding stocks (Pensaert et al. 2004). The affected herds include gilt startups and new populations. PCV2 also replicates in an embryo and may lead to embryonic death and return to oestrus. In a small proportion of embryos, PCV2 did not have any detrimental effect on their development before 21 days of pregnancy (Mateusen et al. 2007).

\subsubsection{PCV2-PDNS}

The most important clinical sign is the presence of irregular red to purple macules and papules in the skin of hind legs and perineal region mostly. Later on lesions become covered by dark-coloured crust, which may fade leaving scar tissue. Other clinical signs are lethargy and fever. It affects nursery, growing and adult pigs with prevalence below $1 \%$ and mortality $100 \%$ in pigs older than 3 months and $50 \%$ in younger age groups (Segalés 2012; Segalés et al. 1998; Drolet et al. 1999).

\subsubsection{PCV2 Subclinical Infection (PCV2-SI)}

It is the most common form. It is characterized by decreased average daily weight gain without any overt clinical signs. Vaccination is helpful in the improvement of productive parameters (Young et al. 2011; Segalés 2012). PCV2 infection may be limited to 1-2 lymph nodes with necrotizing lymphadenitis in clinically healthy pigs.

Initially, PCV2 was found to be associated with type II congenital tremor resulting from myelin deficiency in the USA (Stevenson et al. 2001). But in further study, PCV2 was not found to be associated with congenital tremor in 40 pigs from the UK, Sweden, Spain and Ireland (Kennedy et al. 2003).

PCV2 was also found to be involved in per acute syndrome called as acute pulmonary oedema (APE) affecting nursery and younger finisher pigs. The condition is characterized by rapid onset of respiratory distress leading to death. Often animals are found dead without any obvious clinical signs. The mortality is around $20 \%$ in the affected group. PCV2 multiplies in the endothelial cells and mononuclear cells of lungs of younger animals without any protective antibody level, and pulmonary 
oedema occurs as a result of damage to endothelial cells and release of cytokines from mononuclear cells (Cino-Ozuna et al. 2011; Segalés 2012).

\subsection{Pathology of PCVAD}

In PCV2-SD, the primary gross lesions observed are rough hair coat, prominent backbone, oversized head, enlarged lymph nodes, non-collapsible and mottled tan lungs, white spots in the kidney, discoloured liver, catarrhal enteritis, less commonly gastric ulceration and spleen infarcts. Microscopically, lymphohistiocytic to granulomatous inflammatory lesions were observed in lymphoid tissues mainly the tonsil, spleen, Payer's patches and one to more lymph nodes, lung, liver, kidney, heart and intestine. The characteristic lesions in lymphoid tissue include lymphoid depletion and histiocytic replacement both in follicular and parafollicular area. Multinucleated giant cells are frequently seen. Macrophages containing sharply demarcated spherical basophilic intracytoplasmic botryoid inclusion bodies may also be observed. Scoring system for lesion severity has also been described (Opriessnig et al. 2007). Necrotizing lymphadenitis has also been described in at least one lymph node of $10 \%$ pigs suffering from PCV2-SD which may be due to hypertrophy and hyperplasia of the endothelium of blood vessels and subsequent thrombosis of blood vessels (Segalés et al. 2004; Galindo-Cardiel et al. 2011). Other microscopic lesions are lymphohistiocytic or granulomatous interstitial pneumonia with rare peribronchiolar fibrosis, mild to severe necrotizing bronchiolitis in the lung, interstitial lymphoplasmocytic or granulomatous or mixed-type nephritis, granulomatous enteritis, lymphohistiocytic hepatitis with disorganization of hepatic cords along with apoptosis and perilobular fibrosis in the liver, etc. Lymphohistiocytic and plasmacytic vasculitis has also been observed. Acute necrotizing myocarditis or chronic fibrosing myocarditis along with chronic vasculitis has been reported in PCV2-affected cases (Opriessnig et al. 2006c). Brain lesions are of rare occurrence in PCV2-SD, but lymphohistiocytic vasculitis associated with haemorrhage or lymphohistiocytic meningitis in the cerebellum; degeneration and necrosis of grey and white matter have been reported (Correa et al. 2007; Seeliger et al. 2007; Segalés 2012).

In PCV2-LD, non-collapsible and tan-mottled lungs are observed. Histopathologically, lymphohistiocytic to granulomatous interstitial pneumonia, peribronchiolar fibroplasias and mild to severe necrotizing and ulcerative bronchiolitis are found (Opriessnig et al. 2007).

The lesions in PCV2-ED resemble subacute to chronic ileitis associated with Lawsonia intracellularis. The intestinal mucosa is thickened and mesenteric lymph nodes are enlarged. Histopathologically, granulomatous enteritis and characteristic lesions in Payer's patches are observed (Jensen et al. 2006).

In PCV2-RD, foetal mummification, stillbirths and abortions are observed. Grossly the foetuses are oedematous. Ascites, hydrothorax and hydropericardium are observed. In a foetal heart, cardiac hypertrophy with multifocal areas of discolouration in the myocardium is commonly present. Foetal liver is congested and 
enlarged due to chronic passive congestion. In a foetus, the heart is the target organ for PCV2. Gross lesions are present when foetuses are infected at 57 days of gestation but no gross lesions are observed in foetuses when sows are infected at 75 and 92 days of gestation (Sánchez et al. 2001). Microscopically, non-suppurative to necrotizing or fibrosing myocarditis, chronic venous congestion in the liver and mild pneumonia are observed.

PDNS-affected pigs show necrotizing skin lesions and enlarged tan, waxyappearing kidneys with petechial haemorrhage. Microscopically, systemic necrotizing vasculitis, fibrino-necrotizing glomeruli nephritis and non-purulent interstitial nephritis are prominent lesions which are suggestive of type III hypersensitivity reaction. Mild to moderate lymphoid depletion is also observed in lymphoid tissue (Rosell et al. 2000). In recovered animals, chronic fibrous interstitial nephritis and glomerulosclerosis are observed. In PCV2-SI cases, necrotizing lymphadenitis is present without apparent clinical signs (Kim and Chae 2005). In APE cases, hydrothorax, non-collapsible lung and interstitial oedema are observed. Microscopically, interstitial oedema, alveolar oedema, mononuclear infiltration in the interstitial septa, fibrinoid necrosis of blood vessel and lymphoid depletion in lymphoid tissues are present (Cino-Ozuna et al. 2011).

Recently, PCV3 has been isolated from different pathological conditions like porcine dermatitis and nephropathy syndrome, reproductive failure, cardiac and multisystemic inflammation, pyretic and pneumonic piglets, etc., from different parts of the world.

\subsection{Diagnostics}

The first step towards diagnosis of PCVAD is assessment of clinical signs. But in PCV2-SI, no clinical signs are observed. The second step is histopathology. The PCVAD cannot be confirmed without microscopic evaluation of complete set of tissue samples and demonstration of PCV2 antigen or nucleic acid in that lesion. In PCV2-SD, characteristic histopathological lesions are severe lymphoid depletion and proliferation of histiocytes in the lymphoid tissues. Multinucleated giant cells and botryoid inclusions in the macrophages are also characteristics but not observed in all the cases.

The most common golden standard techniques to detect PCV2 nucleic acid and antigen in the tissue are in situ hybridization (ISH) and immunohistochemistry (IHC) using monoclonal or polyclonal antibody against PCV2, respectively. PCV2 is usually demonstrated in the cytoplasm of histiocytes, multinucleated giant cells, other monocytic or macrophage lineage and dendritic cells and sporadically in the cytoplasm of renal and respiratory epithelial cells, vascular endothelium, acinar and ductular cells of the pancreas, lymphocytes and in the nucleus of macrophage or giant cells, smooth muscle cells, hepatocytes, enterocytes and pancreatic cells (Segalés and Domingo 2002). Both IHC and ISH were able to detect PCV2 in tissues that were stored in formalin for up to 6 months (McNeilly et al. 1999). Nonradioactive digoxigenin probes targeting ORF1 region of PCV1 and ORF2 of PCV2 
are also in use to differentiate two viruses in formalin-fixed paraffin-embedded tissue samples (Kim and Chae 2001). Double ISH using double labelling like digoxigenin and biotinylated probes is used to detect PPV and PCV2 simultaneously in tissue samples, respectively (Kim and Chae 2002). The IHC is more rapid and less expensive than ISH for routine use in laboratory (Sorden et al. 1999). A strong correlation has been observed between the amount of PCV2 and severity of microscopic lesions (Rosell et al. 1999).

Other techniques for detection of PCV2 nucleic acid are PCR and real-time PCR. PCR is the most sensitive technique. Since PCV is ubiquitous in nature, detection of nucleic acid by PCR cannot rule out the actual presence or absence of disease. PCR is used to study the routes of virus excretion and to evaluate PCV status in semen. There are different types of PCR which are in use to detect and quantify PCV nucleic acids. Multiplex PCR is used to detect and differentiate between PCV1 and PCV2 (Larochelle et al. 1999). Multiplex nested PCR assays have been described for simultaneous detection of PCV1, PCV2 and PPV (Kim and Chae 2003). Multiplex PCR for simultaneous detection of six swine viruses such as CSFV, PRRSV, PCV2, JEV, PPV and porcine pseudorabies virus is a very useful approach for clinical diagnosis in mixed infection (Xu et al. 2012). Real-time PCR assays both SYBR Green and TaqMan-based assays have been developed for accurate and rapid quantification of $\mathrm{PCV}$ in serum and tissue samples for early detection of disease as it is a more sensitive method, for correlating virus load with extent of disease, for post-vaccination tracking of viral load in different tissues and for evaluating potency of developmental vaccine (Zhao et al. 2010; Nan-Chang et al. 2010). A severe PCV2-associated lesion was found to be associated with more than or equal to $10^{7}$ (Brunborg et al. 2004). Multiplex real-time PCR is in use for differentiation of various PCV2 genotypes (Gagnon et al. 2008). An ORF2-based PCR has also been used for differentiation between PCV1 and PCV2 and for differentiation of various PCV2 genotypes, respectively (Fenaux et al. 2000; Hamel et al. 2000). Recently, duplex nanoparticle-based PCR has been developed for detection of PCV2 and PCV3 (Zhang et al. 2018).

Virus isolation can be carried out in suitable cell culture system. PCV can multiply in PK 15 cells without causing any gross cytopathic effect (CPE). Multiplication of PCV is found to be increased several times after glucosamine treatment by enabling entry of PCV genome into cell nucleus (Tischer et al. 1987). As no CPE is observed, virus replication is usually detected by PCR or IHC or IFT. As virus isolation is a time-consuming procedure, it is not routinely used for PCV diagnosis.

Sequencing and phylogenetic analysis are very useful for analyzing genetic variation among PCV from different geographical regions for study of molecular epidemiology and molecular evolution (Olvera et al. 2007; Cortey and Segalés 2012; Anoopraj et al. 2015; Palinski et al. 2017).

Various serological tests for detection of antibodies to PCV have been developed. These tests have limited use in diagnosis of diseases associated with PCV because of its ubiquitous nature and similar seroconversion pattern between diseased and clinically healthy animals. However, they can be used as management tools for breeding herds, for determination of timing of infection on the basis of $\operatorname{IgM}$ 
and $\mathrm{IgG}$ antibody levels and for determination of passive antibody level for formulation of future control strategies. Serological tests include indirect fluorescent antibody assay (IFA), serum virus neutralization assay, IgM immunoperoxidase monolayer assay, indirect ELISA, competitive ELISA, etc. (Walker et al. 2000; Opriessnig et al. 2007; Patterson et al. 2008).

\subsection{Prevention and Control}

Vaccination with safe and effective vaccine is traditionally considered to be the most effective method for preventing viral diseases. Currently available commercial vaccines have shown effectiveness in reducing severity of clinical diseases and improving production parameters. The duration of protection period is limited and complete virus eradication has also not been achieved (Afolabi et al. 2017). Vaccination of breeding boar decreases viraemia, systemic viral load and subsequently shedding of virus in semen, which is helpful in controlling vertical transmission of virus through semen. Vaccination of breeding sow also decreases systemic virus load in sow, decreases quantity of virus transferred to progeny during gestation and pre-weaning period and increases neutralizing antibody against PCV2 in colostrum. And passive immunity in the form of maternal antibody decreases pre-weaning mortality and improves average daily weight gain in the offspring. Vaccines administered to growing pigs have shown to decrease virus load and mortality and increase growth performances. Vaccination in the presence of maternal antibody has resulted in decreased vaccine efficacy. But in another study, vaccination in the presence of maternal antibody has been found to be effective (Fort et al. 2008; Opriessnig et al. 2008; Beach and Meng 2012).

Most of commercially available vaccines are based either on whole inactivated PCV2a virus or on its immunogenic Cap protein. The Circovac vaccine (Merial) is composed of inactivated whole PCV2a virus and mineral oil adjuvant; recommended for use in piglets more than 3 weeks age intramuscularly with single dose and for healthy breeding age female pigs, two injections at 3-4 weeks interval before breeding followed by one booster dose 2-4 weeks before farrowing are recommended. Subunit vaccines based on recombinant capsid protein of PCV2a are available which include Ingelvac CircoFLEX (Boehringer Ingelheim Vetmedica Inc.) with carbomer adjuvant, Porcilis PCV (Schering-Plough, Merck) with mineral oil adjuvant and Circumvent PCV (Intervet, Merck) with Microsol Diluvac Forte. They are recommended for piglets above 3 weeks of age. The recent one, FosteraTM PCV (Pfizer), with killed chimeric PCV1 and PCV2a virus and SL-CD aqueous adjuvant is recommended for use in piglets above 3 weeks of age (Beach and Meng 2012; Afolabi et al. 2017).

Vaccination of pigs with PCV2a leads to emergence of vaccine escape strain PCV2b worldwide with severe occurrence of clinical disease (Carman et al. 2008). Although cross protection is observed between PCV2a and PCV2b, vaccine based on genotype PCV2b is more effective against PCV2b than vaccine based on PCV2a (Opriessnig et al. 2013; 2014a, b). Recently, PCV2d genotype has replaced PCV2b 
genotype which is the most prevalent genotype (Xiao et al. 2016). It has also been observed that vaccine with PCV2a can confer adequate cross protection against clinical disease with PCV2d genotype (Opriessnig et al. 2017). In China, commercial vaccines based on inactivated PCV2b (DBN-SX07 strain, WH strain and ZJ/C strain) and PCV2d (SH strain) are in use and licensed for various age groups of pigs (Zhai et al. 2014).

As PCVAD is a multifactorial disease, vaccination along with other interventional strategies is required for effective control of disease. Good management practices like limiting pig to pig contact; decreasing stress, good hygiene, good nutrition and changing genetic background of pigs; use of disinfectant in buildings and transport vehicles; control of coinfection with use of vaccine, antimicrobial, bacterins and anti-inflammatory drugs; and control of other potential factors that induce immune stimulation are essential for controlling disease (Opriessnig et al. 2007).

Acknowledgements All the authors of the manuscript thank and acknowledge their respective universities and institutes.

Conflict of Interest There is no conflict of interest.

\section{References}

Afolabi KO, Iweriebor BC, Okoh AI, Obi LC (2017) Global status of porcine circovirus type 2 and its associated diseases in Sub-Saharan Africa. Adv Virol 2017

Alarcon P, Rushton J, Wieland B (2013) Cost of post-weaning multi-systemic wasting syndrome and porcine circovirus type-2 subclinical infection in England - an economic disease model. Prev Vet Med 110(2):88-102

Allan GM, Ellis JA (2000) Porcine circoviruses: a review. J Vet Diagn Investig 12(1):3-14

Allan GM, Kennedy S, McNeilly F, Foster JC, Ellis JA, Krakowka SJ, Meehan BM, Adair BM (1999) Experimental reproduction of severe wasting disease by co-infection of pigs with porcine circovirus and porcine parvovirus. J Comp Pathol 121(1):1-11

Allan GM, McNeilly F, Ellis J, Krakowka S, Meehan B, McNair I, Walker I, Kennedy S (2000) Experimental infection of colostrum deprived piglets with porcine circovirus 2 (PCV2) and porcine reproductive and respiratory syndrome virus (PRRSV) potentiates PCV2 replication. Arch Virol 145(11):2421-2429

Allan GM, Caprioli A, McNair I, Lagan-Tregaskis P, Ellis J, Krakowka S, McKillen J, Ostanello F, McNeilly F (2007) Porcine circovirus 2 replication in colostrum-deprived piglets following experimental infection and immune stimulation using A modified live vaccine against porcine respiratory and reproductive syndrome virus. Zoonoses Public Health 54(5):214-222

Allan G, Krakowka S, Ellis J, Charreyre C (2012) Discovery and evolving history of two genetically related but phenotypically different viruses, porcine circoviruses 1 and 2 . Virus Res 164(1-2):4-9

Andraud M, Rose N, Grasland B, Pierre JS, Jestin A, Madec F (2009) Influence of husbandry and control measures on porcine circovirus type $2(\mathrm{PCV}-2)$ dynamics within a farrow-to-finish pig farm: a modelling approach. Prev Vet Med 92:38-51

Anoopraj R, John JK, Sethi M, Somvanshi R, Saikumar G (2014) Isolation and identification of porcine circovirus 2 from cases of respiratory disease and postweaning multisystemic wasting syndrome in pigs. Adv Anim Vet Sci 2(6):365-368 
Anoopraj R, Rajkhowa TK, Cherian S, Arya RS, Tomar N, Gupta A, Ray PK, Somvanshi R, Saikumar G (2015) Genetic characterisation and phylogenetic analysis of PCV2 isolates from India: indications for emergence of natural inter-genotypic recombinants. Infect Genet Evol $31: 25-32$

Balmelli C, Steiner E, Moulin H, Peduto N, Herrmann B, Summerfield A, McCullough K (2011) Porcine circovirus type 2 DNA influences cytoskeleton rearrangements in plasmacytoid and monocyte-derived dendritic cells. Immunology 132(1):57-65

Bao F, Mi S, Luo Q, Guo H, Tu C, Zhu G, Gong W (2018) Retrospective study of porcine circovirus type 2 infection reveals a novel genotype PCV2f. Transbound Emerg Dis 65(2):432-440

Beach NM, Meng XJ (2012) Efficacy and future prospects of commercially available and experimental vaccines against porcine circovirus type 2 (PCV2). Virus Res 164(1-2):33-42

Bhattacharjee U, Ahuja A, Sharma I, Karam A, Chakraborty AK, Ghatak S, Puro K, Das S, Shakuntala I, Giri S, Pegu RK (2015) Complete genome sequence of emerging porcine circovirus types $2 \mathrm{a}$ and $2 \mathrm{~b}$ from India. Genome Announc 3(2):e00087-e00015

Blunt R, McOrist S, McKillen J, McNair I, Jiang T, Mellits K (2011) House fly vector for porcine circovirus $2 \mathrm{~b}$ on commercial pig farms. Vet Microbiol 149(3-4):452-455

Brunborg IM, Moldal T, Jonassen CM (2004) Quantitation of porcine circovirus type 2 isolated from serum/plasma and tissue samples of healthy pigs and pigs with postweaning multisystemic wasting syndrome using a TaqMan-based real-time PCR. J Virol Methods 122(2):171-178

Carman S, Cai HY, DeLay J, Youssef SA, McEwen BJ, Gagnon CA, Tremblay D, Hazlett M, Lusis P, Fairles $J$ et al (2008) The emergence of a new strain of porcine circovirus-2 in Ontario and Quebec swine and its association with severe porcine circovirus associated disease-2004-2006. Can J Vet Res 72:259-268

Chang HW, Jeng CR, Lin TL, Liu JJ, Chiou MT, Tsai CY, Chia MY, Jan TR, Pang VF (2006) Immunopathological effects of porcine circovirus type 2 (PCV2) on swine alveolar macrophages by in vitro inoculation. Vet Immunol Immunopathol 110(3-4):207-219

Chang HW, Jeng CR, Lin CM, Liu JJ, Chang CC, Tsai YC, Chia MY, Pang VF (2007) The involvement of Fas/FasL interaction in porcine circovirus type 2 and porcine reproductive and respiratory syndrome virus co-inoculation-associated lymphocyte apoptosis in vitro. Vet Microbiol 122(1-2):72-82

Chang GN, Hwang JF, Chen JT, Tsen HY, Wang JJ (2010) Fast diagnosis and quantification for porcine circovirus type 2 (PCV-2) using real-time polymerase chain reaction. J Microbiol Immunol Infect 43(2):85-92

Chen X, Ren F, Hesketh J, Shi X, Li J, Gan F, Hu Z, Huang K (2013) Interaction of porcine circovirus type 2 replication with intracellular redox status in vitro. Redox Rep 18(5):186-192

Cheng S, Yan W, Gu W, He Q (2014) The ubiquitin-proteasome system is required for the early stages of porcine circovirus type 2 replication. Virology 456:198-204

Choi CY, Rho SB, Kim HS, Han J, Bae J, Lee SJ, Jung WW, Chun T (2015) The ORF3 protein of porcine circovirus type 2 promotes secretion of IL- 6 and IL- 8 in porcine epithelial cells by facilitating proteasomal degradation of regulator of $\mathrm{G}$ protein signalling 16 through physical interaction. J Gen Virol 96(5):1098-1108

Clark EG (1997) Post-weaning multisystemic wasting syndrome. Proc Annu Meet Am Assoc Swine Pract 28:3

Cino-Ozuna AG, Henry S, Hesse R, Nietfeld JC, Bai J, Scott HM, Rowland RR (2011) Characterization of a new disease syndrome associated with porcine circovirus type 2 in previously vaccinated herds. J Clin Microbiol 49(5):2012-2016

Collins PJ, McKillen J, Allan G (2017) Porcine circovirus type 3 in the UK. Vet Rec 181(22):599-599

Correa AM, Zlotowski P, de Barcellos DE, da Cruz CE, Driemeier D (2007) Brain lesions in pigs affected with postweaning multisystemic wasting syndrome. J Vet Diagn Investig 19(1):109-112

Cortey M, Segalés J (2012) Low levels of diversity among genomes of porcine circovirus type 1 (PCV1) points to differential adaptive selection between porcine circoviruses. Virology 422(2):161-164 
Darwich L, Mateu E (2012) Immunology of porcine circovirus type 2 (PCV2). Virus Res 164(1-2):61-67

Darwich L, Balasch M, Plana-Durán J, Segalés J, Domingo M, Mateu E (2003a) Cytokine profiles of peripheral blood mononuclear cells from pigs with postweaning multisystemic wasting syndrome in response to mitogen, superantigen or recall viral antigens. J Gen Virol 84(12):3453-3457

Darwich L, Pie S, Rovira A, Segalés J, Domingo M, Oswald IP, Mateu E (2003b) Cytokine mRNA expression profiles in lymphoid tissues of pigs naturally affected by postweaning multisystemic wasting syndrome. J Gen Virol 84:2117-2125

De Boisseson C, Beven V, Bigarre L, Thiery R, Rose N, Eveno E, Madec F, Jestin A (2004) Molecular characterization of porcine circovirus type 2 isolates from post-weaning multisystemic wasting syndrome-affected and non-affected pigs. J Gen Virol 85(2):293-304

Doster AR, Subramaniam S, Yhee JY, Kwon BJ, Yu CH, Kwon SY, Osorio FA, Sur JH (2010) Distribution and characterization of IL-10-secreting cells in lymphoid tissues of PCV2-infected pigs. J Vet Sci 11(3):177-183

Drolet R, Thibault S, D'Allaire S, Thomson JR, Done SH (1999) Porcine dermatitis and nephropathy syndrome (PDNS): an overview of the disease. J Swine Health Prod 7:283-285

Dupont K, Nielsen EO, Baekbo P, Larsen LE (2008) Genomic analysis of PCV2 isolates from Danish archives and a current PMWS case-control study supports a shift in genotypes with time. Vet Microbiol 128:56-64

Ellis JE (2003) Porcine circovirus: an old virus in a new guise causes an emerging disease through a novel pathogenesis. Large Anim Vet Rounds 3:1-6

Ellis JA, Bratanich A, Clark EG, Allan GM, Meehan BM, Haines DM, Harding J, West KH, Krakowka S, Konoby C, Hassard L, Martin K, McNeilly F (2000) Co-infection by porcine circovirus and porcine parvovirus in pigs with multisystemic wasting syndrome. J Vet Diagn Investig 12(1):21-27

Fabisiak M, Szczotka A, Podgórska K, Stadejek T (2012) Prevalence of infection and genetic diversity of porcine circovirus type 2 (PCV2) in wild boar (Sus scrofa) in Poland. J Wildl Dis 48(3):612-618

Faccini S, Barbieri I, Gilioli A, Sala G, Gibelli LR, Moreno A, Sacchi C, Rosignoli C, Franzini G, Nigrelli A (2017) Detection and genetic characterization of porcine circovirus type 3 in Italy. Transbound Emerg Dis 64(6):1661-1664

Fenaux M, Halbur PG, Gill M, Toth TE, Meng XJ (2000) Genetic characterization of type 2 porcine circovirus (PCV-2) from pigs with postweaning multisystemic wasting syndrome in different geographic regions of North America and development of a differential PCR-restriction fragment length polymorphism assay to detect and differentiate between infections with PCV-1 and PCV-2. J Clin Microbiol 38(7):2494-2503

Fenaux M, Opriessnig T, Halbur PG, Elvinger F, Meng XJ (2004) Two aminoacid mutations in the capsid protein of type 2 porcine circovirus (PCV2) enhanced PCV2 replication in vitro and attenuated the virus in vivo. J Virol 78(24):13440-13446

Fort M, Sibila M, Allepuz A, Mateu E, Roerink F, Segalés J (2008) Porcine circovirus type 2 (PCV2) vaccination of conventional pigs prevents viremia against PCV2 isolates of different genotypes and geographic origins. Vaccine 26(8):1063-1071

Gagnon C, Tremblay D, Tijssen P, Venne MH, Houde A, Elahi SM (2007) PCV2 strain variation: what does it mean? Proc Am Assoc Swine Vet 38:535-540

Gagnon CA, Del Castillo JR, Music N, Fontaine G, Harel J, Tremblay D (2008) Development and use of a multiplex real-time quantitative polymerase chain reaction assay for detection and differentiation of porcine circovirus-2 genotypes $2 \mathrm{a}$ and $2 \mathrm{~b}$ in an epidemiological survey. $\mathrm{J}$ Vet Diagn Investig 20(5):545-558

Gagnon CA, Music N, Fontaine G, Tremblay D, Harel J (2010) Emergence of a new type of porcine circovirus in swine (PCV): a type 1 and type 2 PCV recombinant. Vet Microbiol 144:18-23

Galindo-Cardiel I, Grau-Roma L, Pérez-Maillo M, Segalés J (2011) Characterization of necrotizing lymphadenitis associated with porcine circovirus type 2 infection. J Comp Pathol 144(1):63-69 
Gan F, Zhang Z, Hu Z, Hesketh J, Xue H, Chen X, Hao S, Huang Y, Ezea PC, Parveen F, Huang K (2015) Ochratoxin A promotes porcine circovirus type 2 replication in vitro and in vivo. Free Radic Biol Med 80:33-47

Grau-Roma L, Fraile L, Segalés J (2011) Recent advances in the epidemiology, diagnosis and control of diseases caused by porcine circovirus type 2 . Vet J 187:23-32

Grierson SS, King DP, Wellenberg GJ, Banks M (2004) Genomesequence analysis of 10 Dutch porcine circovirus type 2 (PCV-2) isolates from a PMWS case-control study. Res Vet Sci 77(3):265-268

Ha Y, Lee YH, Ahn KK, Kim B, Chae C (2008) Reproduction of postweaning multisystemic wasting syndrome in pigs by prenatal porcine circovirus 2 infection and postnatal porcine parvovirus infection or immunostimulation. Vet Pathol 45(6):842-848

Ha Y, Ahn KK, Kim B, Cho K-D, Lee BH, Oh Y-S, Kim S-H, Chae C (2009) Evidence of shedding of porcine circovirus type 2 in milk from experimentally infected sows. Res Vet Sci 86(1):108-110

Hamel AL, Lin LL, Nayar GP (1998) Nucleotide sequence of porcine circovirus associated with postweaning multisystemic wasting syndrome in pigs. J Virol 72(6):5262-5267

Hamel AL, Lin LL, Sachvie C, Grudeski E, Nayar GP (2000) PCR detection and characterization of type-2 porcine circovirus. Can J Vet Res 64(1):44

Harding JC (1996) Post-weaning multisystemic wasting syndrome: preliminary epidemiology and clinical findings. Proceedings of West Can. Association of Swine Practitioners. p 21

Harding JC, Clark EG (1997) Recognizing and diagnosing postweaning multisystemic wasting syndrome (PMWS). J Swine Health Prod 5:201-203

He J, Cao J, Zhou N, Jin Y, Wu J, Zhou J (2013) Identification and functional analysis of the novel ORF4 protein encoded by porcine circovirus type 2. J Virol 87(3):1420-1429

Huang S, Yu X, Yang L, Song F, Chen G, Lv Z, Li T, Chen D, Zhu W, Yu A, Zhang Y (2014) The efficacy of nimodipine drug delivery using mPEG-PLA micelles and mPEG-PLA/TPGS mixed micelles. Eur J Pharm Sci 63:187-198

Jacobsen B, Krueger L, Seeliger F, Bruegmann M, Segalés J, Baumgaertner W (2009) Retrospective study on the occurrence of porcine circovirus 2 infection and associated entities in northern Germany. Vet Microbiol 138(1-2):27-33

Jensen TK, Vigre H, Svensmark B, Bille-Hansen V (2006) Distinction between porcine circovirus type 2 enteritis and porcine proliferative enteropathy caused by Lawsonia intracellularis. J Comp Pathol 135:176-182

Johnson CS, Joo HS, Direksin K, Yoon KJ, Choi YK (2002) Experimental in utero inoculation of late-term swine fetuses with porcine circovirus type 2. J Vet Diagn Investig 14(6):507-512

Karuppannan AK, Ramesh A, Reddy YK, Ramesh S, Mahaprabhu R, Jaisree S, Roy P, Sridhar R, Pazhanivel N, Sakthivelan SM, Sreekumar C (2016) Emergence of porcine circovirus 2 associated reproductive failure in Southern India. Transbound Emerg Dis 63(3):314-320

Kawashima K, Tsunemitsu H, Horino R et al (2003) Effects of dexamethasone on the pathogenesis of porcine circovirus type 2 infection in piglets. J Comp Pathol 129:294-302

Kennedy S, Segalés J, Rovira A, Scholes S, Domingo M, Moffett D, Meehan B, O’Neill R, McNeilly F, Allan G (2003) Absence of evidence of porcine circovirus infection in piglets with congenital tremors. J Vet Diagn Investig 15(2):151-156

Kim J, Chae C (2001) Differentiation of porcine circovirus 1 and 2 in formalin-fixed, paraffinwax-embedded tissues from pigs with postweaning multisystemic wasting syndrome by in-situ hybridisation. Res Vet Sci 70(3):265-269

Kim J, Chae C (2002) Simultaneous detection of porcine circovirus 2 and porcine parvovirus in naturally and experimentally coinfected pigs by double in situ hybridization. J Vet Diagn Investig 14(3):236-240

Kim J, Chae C (2003) Multiplex nested PCR compared with in situ hybridization for the differentiation of porcine circoviruses and porcine parvovirus from pigs with postweaning multisystemic wasting syndrome. Can J Vet Res 67(2):133

Kim J, Chae C (2005) Necrotising lymphadenitis associated with porcine circovirus type 2 in pigs. Vet Rec 156(6):177-178 
Kim J, Chung HK, Chae C (2003a) Association of porcine circovirus 2 with porcine respiratory disease complex. Vet J 166(3):251-256

Kim J, Han DU, Choi C, Chae C (2003b) Simultaneous detection and differentiation between porcine circovirus and porcine parvovirus in boar semen by multiplex seminested polymerase chain reaction. J Vet Med Sci 65(6):741-744

Kim J, Ha Y, Jung K, Choi C, Chae C (2004) Enteritis associated with porcine circovirus 2 in pigs. Can J Vet Res 68(3):218-221

Krakowka S, Ellis JA, McNeilly F, Gilpin D, Meehan B, McCullough K, Allan G (2002) Immunologic features of porcine circovirus type 2 infection. Viral Immunol 15(4):567-582

Krakowka S, Ellis J, McNeilly F, Waldner C, Rings DM, Allan G (2007) Mycoplasma hyopneumoniae bacterins and porcine circovirus type 2 (PCV2) infection: induction of postweaning multisystemic wasting syndrome (PMWS) in the gnotobiotic swine model of PCV2-associated disease. Can Vet J 48(7):716

Ku X, Chen F, Li P, Wang Y, Yu X, Fan S, Qian P, Wu M, He Q (2017) Identification and genetic characterization of porcine circovirus type 3 in China. Transbound Emerg Dis 64:703-708

Kumar SK, Selvaraj R, Hariharan T, Chanrahassan C, Reddy YKM (2014) Porcine Circovirus-2 an emerging disease of crossbred pigs in Tamil Nadu, India. Int J Sci Environ Technol 3:1268-1272

Kwon T, Yoo SJ, Park CK, Lyoo YS (2017) Prevalence of novel porcine circovirus 3 in Korean pig populations. Vet Microbiol 207:178-180

Larochelle R, Antaya M, Morin M, Magar R (1999) Typing of porcine circovirus in clinical specimens by multiplex PCR. J Virol Methods 80(1):69-75

Larochelle R, Bielanski A, Müller P, Magar R (2000) PCR detection and evidence of shedding of porcine circovirus type 2 in boar semen. J Clin Microbiol 38(12):4629-4632

Li L, Shan T, Soji OB, Alam MM, Kunz TH, Zaidi SZ, Delwart E (2011) Possible cross-species transmission of circoviruses and cycloviruses among farm animals. J Gen Virol 92(4):768-772

Liu Q, Wang L, Willson P, O'Connor B, Keenliside J, Chirino-Trejo M, Meléndez R, Babiuk L (2002) Seroprevalence of porcine circovirus type 2 in swine populations in Canada and Costa Rica. Can J Vet Res 66(4):225

Liu J, Chen I, Du Q, Chua H, Kwang J (2006) The ORF3 protein of porcine circovirus type 2 is involved in viral pathogenesis in vivo. J Virol 80(10):5065-5073

Liu J, Zhu Y, Chen I, Lau J, He F, Lau A, Wang Z, Karuppannan AK, Kwang J (2007) The ORF3 protein of porcine circovirus type 2 interacts with porcine ubiquitin E3 ligase Pirh2 and facilitates p53 expression in viral infection. J Virol 81(17):9560-9567

Liu J, Bai J, Zhang L, Jiang Z, Wang X, Li Y, Jiang P (2013) Hsp70 positively regulates porcine circovirus type 2 replication in vitro. Virology 447(1-2):52-62

Liu J, Zhang L, Zhu X, Bai J, Wang L, Wang X, Jiang P (2014) Heat shock protein 27 is involved in PCV2 infection in PK-15 cells. Virus Res 189:235-242

Lopez-Soria S, Nofrarias M, Calsamiglia M, Espinal A, Valero O, Ramirez-Mendoza H, Minguez A, Serrano JM, Marin O, Callén A, Segalés J (2011) Post-weaning multisystemic wasting syndrome (PMWS) clinical expression under field conditions is modulated by the pig genetic background. Vet Microbiol 149(3-4):352-357

Madson DM, Ramamoorthy S, Kuster C, Pal N, Meng XJ, Halbur PG, Opriessnig T (2008) Characterization of shedding patterns of porcine circovirus types $2 \mathrm{a}$ and $2 \mathrm{~b}$ in experimentally inoculated mature boars. J Vet Diagn Investig 20(6):725-734

Mandrioli L, Sarli G, Panarese S, Baldoni S, Marcato PS (2004) Apoptosis and proliferative activity in lymph node reaction in postweaning multisystemic wasting syndrome (PMWS). Vet Immunol Immunopathol 97(1-2):25-37

Mankertz A, Caliskan R, Hattermann K, Hillenbrand B, Kurzendoerfer P, Mueller B, Schmitt C, Steinfeldt T, Finsterbusch T (2004) Molecular biology of porcine circovirus: analyses of gene expression and viral replication. Vet Microbiol 98(2):81-88

Mateusen B, Maes DG, Van Soom A, Lefebvre D, Nauwynck HJ (2007) Effect of a porcine circovirus type 2 infection on embryos during early pregnancy. Theriogenology 68(6):896-901 
McIntosh KA, Harding JC, Parker S, Ellis JA, Appleyard GD (2006) Nested polymerase chain reaction detection and duration of porcine circovirus type 2 in semen with sperm morphological analysis from naturally infected boars. J Vet Diagn Investig 18(4):380-384

McNeilly F, Kennedy S, Moffett D, Meehan BM, Foster JC, Clarke EG, Ellis JA, Haines DM, Adair BM, Allan GM (1999) A comparison of in situ hybridization and immunohistochemistry for the detection of a new porcine circovirus in formalin-fixed tissues from pigs with postweaning multisystemic wasting syndrome (PMWS). J Virol Methods 80(2):123-128

Meehan BM, McNeilly F, Todd D, Kennedy S, Jewhurst VA, Ellis JA, Hassard LE, Clark EG, Haines DM, Allan GM (1998) Characterization of novel circovirus DNAs associated with wasting syndromes in pigs. J Gen Virol 79(Pt 9):2171-2179

Misinzo G, Meerts P, Bublot M, Mast J, Weingartl HM, Nauwynck HJ (2005) Binding and entry characteristics of porcine circovirus 2 in cells of the porcine monocytic line 3D4/31. J Gen Virol 86(7):2057-2068

Misinzo G, Delputte PL, Meerts P, Lefebvre DJ, Nauwynck HJ (2006) Porcine circovirus 2 uses heparan sulfate and chondroitin sulfate B glycosaminoglycans as receptors for its attachment to host cells. J Virol 80(7):3487-3494

Misinzo G, Delputte PL, Nauwynck HJ (2008) Inhibition of endosome-lysosome system acidification enhances porcine circovirus 2 infection of porcine epithelial cells. J Virol 82(3):1128-1135

Misinzo G, Delputte PL, Lefebvre DJ, Nauwynck HJ (2009) Porcine circovirus 2 infection of epithelial cells is clathrin-, caveolae- and dynamin-independent, actin and Rho-GTPase-mediated, and enhanced by cholesterol depletion. Virus Res 139(1):1-9

Mukherjee P, Karam A, Barkalita L, Borah P, Chakraborty AK, Das S, Puro K, Sanjukta R, Ghatak S, Shakuntala I, Laha RG (2018a) Porcine circovirus 2 in the North Eastern region of India: disease prevalence and genetic variation among the isolates from areas of intensive pig rearing. Acta Trop 182:166-172

Mukherjee P, Karam A, Singh U, Chakraborty AK, Huidrom S, Sen A, Sharma I (2018b) Seroprevalence of selected viral pathogens in pigs reared in organized farms of Meghalaya from 2014 to 16. Vet World 11(1):42-47

Nattrat T, Sangthong P, Poolperm P, Thanantong N, Boonsoongnem A, Hansoongnem P, Semkum P, Petcharat N, Lekcharoensuk P (2017) Genetic diversity of porcine circovirus type 2 (PCV2) in Thailand during 2009-2015. Vet Microbiology 208:239-246

Olvera A, Cortey M, Segalés J (2007) Molecular evolution of porcine circovirus type 2 genomes: phylogeny and clonality. Virology 357:175-185

Opriessnig T, Halbur PG (2012) Concurrent infections are important for expression of porcine circovirus associated disease. Virus Res 164:20-32

Opriessnig T, Thacker EL, Yu S, Fenaux M, Meng XJ, Halbur PG (2004) Experimental reproduction of postweaning multisystemic wasting syndrome in pigs by dual infection with Mycoplasma hyopneamoniae and porcine circovirus type 2. Vet Pathol 41(6):624-640

Opriessnig T, Fenaux M, Thomas P, Hoogland MJ, Rothschild MF, Meng XJ, Halbur PG (2006a) Evidence of breed-dependent differences in susceptibility to porcine circovirus type-2associated disease and lesion. Vet Pathol 43(3):281-293

Opriessnig T, Kuster C, Halbur PG (2006b) Demonstration of porcine circovirus type 2 in the testes and accessory sex glands of a boar. J Swine Health Prod 14(1):42-45

Opriessnig T, Janke BH, Halbur PG (2006c) Cardiovascular lesions in pigs naturally or experimentally infected with porcine circovirus type 2. J Comp Pathol 134(1):105-110

Opriessnig T, Meng XJ, Halbur PG (2007) Porcine circovirus type 2-associated disease: update on current terminology, clinical manifestations, pathogenesis, diagnosis, and intervention strategies. J Vet Diagn Investig 19(6):591-615

Opriessnig T, Patterson AR, Elsener J, Meng XJ, Halbur PG (2008) Influence of maternal antibodies on efficacy of porcine circovirus type 2 (PCV2) vaccination to protect pigs from experimental infection with PCV2. Clin Vaccine Immunol 15(3):397-401

Opriessnig T, O'Neill K, Gerber PF, de Castro AM, Giminez-Lirola LG, Beach NM, Zhou L, Meng XJ, Wang C, Halbur PG (2013) A PCV2 vaccine based on genotype 2b is more effective 
than a 2a-based vaccine to protect against PCV2b or combined PCV2a/2b viremia in pigs with concurrent PCV2, PRRSV and PPV infection. Vaccine 31(3):487-494

Opriessnig T, Gerber PF, Xiao C-T, Halbur PG, Matzinger SR, Meng X-J (2014a) Commercial PCV2a-based vaccines are effective in protecting naturally PCV2b-infected finisher pigs against experimental challenge with a 2012 mutant PCV2. Vaccine 32:4342-4348

Opriessnig T, Gerber PF, Xiao C-T, Mogler M, Halbur PG (2014b) A commercial vaccine based on PCV2a and an experimental vaccine based on a variant mPCV2b are both effective in protecting pigs against challenge with a 2013 U.S. variant mPCV2b strain. Vaccine 32:230-237

Opriessnig T, Xiao CT, Halbur PG, Gerber PF, Matzinger SR, Meng XJ (2017) A commercial porcine circovirus (PCV) type 2a-based vaccine reduces PCV2d viremia and shedding and prevents PCV2d transmission to naïve pigs under experimental conditions. Vaccine 35(2):248-254

Palinski R, Piñeyro P, Shang P, Yuan F, Guo R, Fang Y, Byers E, Hause BM (2017) A novel porcine circovirus distantly related to known circoviruses is associated with porcine dermatitis and nephropathy syndrome and reproductive failure. J Virol 91(1):e01879-e01816

Patterson AR, Johnson J, Ramamoorthy S, Meng XJ, Halbur PG, Opriessnig T (2008) Comparison of three enzyme-linked immunosorbent assays to detect porcine Circovirus-2 (PCV-2) - specific antibodies after vaccination or inoculation of pigs with distinct PCV-1 or PCV-2 isolates. J Vet Diagn Investig 20(6):744-751

Pegu SR, Sarma DK, Rajkhowa S, Choudhury M (2017) Sero-prevelance and pathology of important viral pathogens causing reproductive problems in domestic pigs of NE India

Park JS, Kim J, Ha Y, Jung K, Choi C, Lim JK, Kim SH, Chae C (2005) Birth abnormalities in pregnant sows infected intranasally with porcine circovirus 2. J Comp Pathol 132(2-3):139-144

Pensaert MB, Sánchez RE Jr, Ladekjaer-Mikkelsen AS, Allan GM, Nauwynck HJ (2004) Viremia and effect of fetal infection with porcine viruses with special reference to porcine circovirus 2 infection. Vet Microbiol 98(2):175-183

Phan TG, Giannitti F, Rossow S, Marthaler D, Knutson TP, Li L, Deng X, Resende T, Vannucci F, Delwart E (2016) Detection of a novel circovirus PCV3 in pigs with cardiac and multi-systemic inflammation. Virol J 13:184

Rodríguez-Cariño C, Duffy C, Sánchez-Chardi A, McNeilly F, Allan GM, Segalés J (2011) Porcine circovirus type 2 morphogenesis in a clone derived from the 135 lymphoblastoid cell line. J Comp Pathol 144(2-3):91-102

Rose N, Opriessnig T, Grasland B, Jestin A (2012) Epidemiology and transmission of porcine circovirus type 2 (PCV2). Virus Res 164:78-89

Rosell C, Segalés J, Plana-Duran J, Balasch M, Rodriguez-Arrioja GM, Kennedy S, Allan GM, McNeilly F, Latimer KS, Domingo M (1999) Pathological, immunohistochemical, and insitu hybridization studies of natural cases of postweaning multisystemic wasting syndrome (PMWS) in pigs. J Comp Pathol 120(1):59-78

Rosell C, Segalés J, Ramos-Vara JA, Folch JM, Rodríguez-Arrioja GM, Duran CO, Balasch M, Plana-Duran J, Domingo M (2000) Identification of porcine circovirus in tissues of pigs with porcine dermatitis and nephropathy syndrome. Vet Rec 146(2):40-43

Sánchez RE Jr, Nauwynck HJ, McNeilly F, Allan GM, Pensaert MB (2001) Porcine circovirus 2 infection in swine foetuses inoculated at different stages of gestation. Vet Microbiol 83(2):169-176

Saraiva GL, Vidigal PMP, Fietto JLR, Bressan GC, Júnior AS, de Almeida MR (2018) Evolutionary analysis of porcine circovirus 3 (PCV3) indicates an ancient origin for its current strains and a worldwide dispersion. Virus Genes:1-9

Seeliger FA, Brugmann ML, Kruger L, Greiser-Wilke I, Verspohl J, Segalés J, Baumgartner W (2007) Porcine circovirus type 2-associated cerebellar vasculitis in postweaning multisystemic wasting syndrome (PMWS)-affected pigs. Vet Pathol 44(5):621-634

Segalés J (2012) Porcine circovirus type 2 (PCV2) infections: clinical signs, pathology and laboratory diagnosis. Virus Res 164(1-2):10-19

Segalés J, Domingo M (2002) Postweaning multisystemic wasting syndrome (PMWS) in pigs. A review. Vet Q 24(3):109-124 
Segalés J, Piella J, Marco E, Mateu-de-Antonio EM, Espuna E, Domingo M (1998) Porcine dermatitis and nephropathy syndrome in Spain. Vet Rec 142(18):483-486

Segalés J, Rosell C, Domingo M (2004) Pathological findings associated with naturally acquired porcine circovirus type 2 associated disease. Vet Microbiol 98(2):137-149

Segalés J, Allan GM, Domingo M (2005) Porcine circovirus diseases. Anim Health Res Rev 6(2):119-142

Segalés J, Olvera A, Grau-Roma L, Charreyre C, Nauwynck H, Larsen L, Dupont K, McCullough K, Ellis J, Krakowka S, Mankertz A, Fredholm M, Fossum C, Timmusk S, StockhofeZurwieden N, Beattie V, Armstrong D, Grassland B, Baekbo P, Allan G (2008) PCV-2 genotype definition and nomenclature. Vet Rec 162:867-868

Segalés J, Kekarainen T, Cortey M (2013) The natural history of porcine circovirus type 2: from an inoffensive virus to a devastating swine disease? Vet Microbiol 165(1-2):13-20

Sharma R, Saikumar G (2010) Porcine parvovirus-and porcine circovirus 2-associated reproductive failure and neonatal mortality in crossbred Indian pigs. Trop Anim Health Prod 42(3):515-522

Shen HG, Loiacono CM, Halbur PG et al (2012) Age-dependent susceptibility to porcine circovirus type 2 infections is likely associated with declining levels of maternal antibodies. J Swine Health Prod 20(1):17-24

Shen H, Liu X, Zhang P, Wang L, Liu Y, Zhang L, Liang P, Song C (2017) Genome characterization of a porcine circovirus type 3 in South China. Transbound Emerg Dis 65(1):264-266. https://doi.org/10.1111/tbed.12639

Shibata I, Okuda Y, Kitajima K, Asai T (2006) Shedding of porcine circovirus into colostrum of sows. J Vet Med B Infect Dis Vet Public Health 53(6):278-280

Sorden SD, Harms PA, Nawagitgul P, Cavanaugh D, Paul PS (1999) Development of a polyclonalantibody-based immunohistochemical method for the detection of type 2 porcine circovirus in formalin-fixed, paraffin-embedded tissue. J Vet Diagn Investig 11(6):528-530

Stadejek T, Woźniak A, Miłek D, Biernacka K (2017) First detection of porcine circovirus type 3 on commercial pig farms in Poland. Transbound Emerg Dis 64(5):1350-1353

Stevenson GW, Kiupel M, Mittal SK, Choi J, Latimer KS, Kanitz CL (2001) Tissue distribution and genetic typing of porcine circoviruses in pigs with naturally occurring congenital tremors. J Vet Diagn Investig 13(1):57-62

Tang Q, Li S, Zhang H, Wei Y, Wu H, Liu J, Wang Y, Liu D, Zhang Z, Liu C (2013) Correlation of the cyclin A expression level with porcine circovirus type 2 propagation efficiency. Arch Virol 158(12):2553-2560

Tischer I, Rasch R, Tochtermann G, Zentralbl Bakteriol Orig A (1974) Characterization of papovavirus-and picornavirus-like particles in permanent pig kidney cell lines. 226(2):153-167

Tischer I, Mields W, Wolff D, Vagt M, Griem W (1986) Studies on epidemiology and pathogenicity of porcine circovirus. Arch Virol 91(3-4):271-276

Tischer I, Peters D, Rasch R, Pociuli S (1987) Replication of porcine circovirus: induction by glucosamine and cell cycle dependence. Arch Virol 96(1-2):39-57

Tischer I, Bode L, Apodaca J, Timm H, Peters D, Rasch R, Pociuli S, Gerike E (1995) Presence of antibodies reacting with porcine circovirus in sera of humans, mice, and cattle. Arch Virol 140:1427-1439

Verreault D, Létourneau V, Gendron L, Massé D, Gagnon CA, Duchaine C (2010) Airborne porcine circovirus in Canadian swine confinement buildings. Vet Microbiol 141(3-4):224-230

Vincent IE, Carrasco CP, Herrmann B, Meehan BM, Allan GM, Summerfield A, McCullough KC (2003) Dendritic cells harbor infectious porcine circovirus type 2 in the absence of apparent cell modulation or replication of the virus. J Virol 77(24):13288-13300

Vincent IE, Balmelli C, Meehan B, Allan G, Summerfield A, McCullough KC (2007) Silencing of natural interferon producing cell activation by porcine circovirus type 2 DNA. Immunology 120(1):47-56

Walker IW, Konoby CA, Jewhurst VA, McNair I, McNeilly F, Meehan BM, Cottrell TS, Ellis JA, Allan GM (2000) Development and application of a competitive enzyme-linked immunosorbent assay for the detection of serum antibodies to porcine circovirus type 2. J Vet Diagn Investig 12(5):400-405 
Wang F, Guo X, Ge X, Wang Z, Chen Y, Cha Z, Yang H (2009) Genetic variation analysis of Chinese strains of porcine circovirus type 2. Virus Res 145:151-156

Wang X, Li W, Xu X, Wang W, He K, Fan H (2018) Phylogenetic analysis of two goat-origin PCV2 isolates in China. Gene 651:57-61

Wei L, Zhu S, Wang J, Liu J (2012) Activation of the phosphatidylinositol 3-kinase/Akt signaling pathway during porcine circovirus type 2 infection facilitates cell survival and viral replication. J Virol 86(24):13589-13597

Wei L, Zhu S, Wang J, Zhang C, Quan R, Yan X, Liu J (2013) Regulatory role of ASK1 in porcine circovirus type 2-induced apoptosis. Virology 447(1-2):285-291

West KH, Bystrom JM, Wojnarowicz C, Shantz N, Jacobson M, Allan GM, Haines DM, Clark EG, Krakowka S, McNeilly F, Konoby C, Martin K, Ellis JA (1999) Myocarditis and abortion associated with intrauterine infection of sows with porcine circovirus 2. J Vet Diagn Investig 11(6):530-532

Xiao CT, Halbur PG, Opriessnig T (2015) Global molecular genetic analysis of porcine circovirus type 2 (PCV2) sequences confirms the presence of four main PCV2 genotypes and reveals a rapid increase of PCV2d. J Gen Virol 96:1830-1841

Xiao CT, Harmon KM, Halbur PG, Opriessnig T (2016) PCV2d-2 is the predominant type of PCV2 DNA in pig samples collected in the US during 2014-2016. Vet Microbiol 197:72-77

Xu XG, Chen GD, Huang Y, Ding L, Li ZC, Chang CD, Wang CY, Tong DW, Liu HJ (2012) Development of multiplex PCR for simultaneous detection of six swine DNA and RNA viruses. J Virol Methods 183(1):6

Yang X, Hou L, Ye J, He Q, Cao S (2012) Detection of porcine circovirus type 2 (PCV2) in mosquitoes from pig farms by PCR. Pak Vet J 32:134-135

Ye X, Berg M, Fossum C, Wallgren P, Blomström AL (2018) Detection and genetic characterisation of porcine circovirus 3 from pigs in Sweden. Virus genes:1-4

Young MG, Cunningham GL, Sanford SE (2011) Circovirus vaccination in pigs with subclinical porcine circovirus type 2 infection complicated by ileitis. J Swine Health Prod 19(3):175-180

Yu S, Opriessnig T, Kitikoon P, Nilubol D, Halbur PG, Thacker E (2007) Porcine circovirus type 2 (PCV2) distribution and replication in tissues and immune cells in early infected pigs. Vet Immunol Immunopathol 115(3-4):261-272

Yu S, Halbur PG, Thacker E (2009) Effect of porcine circovirus type 2 infection and replication on activated porcine peripheral blood mononuclear cells in vitro. Vet Immunol Immunopathol 127(3-4):350-356

Yuzhang S, Dai Y, Yin R (2016) Prevalence and epidemiological analysis of porcine circovirus type 2 in China from 2013 to 2015. J of Appl Virol 5(1). https://doi.org/10.21092/jav.v5i1.57

Zhai SL, Chen SN, Wei ZZ, Zhang JW, Huang L, Lin T, Yue C, Ran DL, Yuan SS, Wei WK, Long JX (2011) Co-existence of multiple strains of porcine circovirus type 2 in the same pig from China. Virol J 8:517

Zhai SL, Chen SN, Zhang JW, Wei ZZ, Long JX, Yuan SS, Wei WK, Chen QL, Xuan H, Wu DC (2012) Dissection of the possible routes on porcine circoviruses infecting human. J Anim Vet Adv 11:1281-1286

Zhai SL, Chen SN, Xu ZH, Tang MH, Wang FG, Li XJ, Sun BB, Deng SF, Hu J, Lv DH, Wen XH (2014) Porcine circovirus type 2 in China: an update on and insights to its prevalence and control. Virol J 11(1):88

Zhai SL, Chen SN, Liu W, Li XP, Deng SF, Wen XH, Luo ML, Lv DH, Wei WK, Chen RA (2016) Molecular detection and genome characterization of porcine circovirus type 2 in rats captured on commercial swine farms. Arch Virol 161(11):3237-3244

Zhai SL, Zhou X, Lin T, Zhang H, Wen XH, Zhou XR, Jia CL, Tu D, Zhu XL, Chen QL, Wei WK (2017) Reappearance of buffalo-origin-like porcine circovirus type 2 strains in swine herds in southern China. New Microbes New Infect 17:98-100 
Zhang L, Luo Y, Liang L, Li J, Cui S (2018) Phylogenetic analysis of porcine circovirus type 3 and porcine circovirus type 2 in China detected by duplex nanoparticle-assisted PCR. Infect Genet Evol 60:1-6

Zhao K, Han F, Zou Y, Zhu L, Li C, Xu Y, Zhang C, Tan F, Wang J, Tao S, He X (2010) Rapid detection of porcine circovirus type 2 using a TaqMan-based real-time PCR. Virol J 7(1):374

Zheng S, Wu X, Zhang L, Xin C, Liu Y, Shi J, Peng Z, Xu S, Fu F, Yu J, Sun W, Xu S, Li J, Wang J (2017) The occurrence of porcine circovirus 3 without clinical infection signs in Shandong province. Transbound Emerg Dis 64(5):1337-1341 